\title{
ARTICLE \\ Investor Sentiment and Cross-Sectional Return after Share Issuance: Evidence from Seasonal Equity Offering in China Market
}

\section{Di Liu*}

Central University of Finance and Economics, Chinese Academy of Finance and Development, Beijing, 100081, China

\begin{tabular}{l}
\hline ARTICLE INFO \\
\hline Article history \\
Received: 6 March 202 \\
Revised: 13 March 2020 \\
Accepted: 9 April 2020 \\
Published Online: 16 April 2020 \\
\hline
\end{tabular}

\section{Keywords:}

Investor sentiment

Cross-sectional return

Seasonal equity offering

China market

\section{Introduction}

$\mathrm{T}$ The debate of relation between firm's equity financing activities, including seasonal equity offering (SEO), stock merger, stock repurchase, etc., and its capital market performance exists in academia as well as industry for a long time. Numerous of literature summarizes the mispricing story behind equity issuance, but in different directions. Some scholars argue the market timing hypothesis stating that firms prefer to equity financing when it is overvalued. A CEO survey by Graham and Harvey (2001) shows that valuation of the firm has an important impact on equity financing decision-making process. After the examination of capital structure and market value, Baker and Wurgler (2002) show that firms tend to issue equity instead of debt when market value is

\begin{abstract}
Our research on private placement of equity on China capital market reveals that firms prefer to equity financing when their stock price is overvalued and investor sentiment is high, following the market timing hypothesis. However, after private issuance, we document a significant positive abnormal return within three years. We believe firms choose to polish their financial statement before the exit of institutional investors and controlling shareholders. Through manipulation of discretional accruals, firms improve the profitability and market valuation, and help institutional investors and controlling shareholders obtain the abnormal return after private placement of equity. Nevertheless, such manipulation cannot be sustained and will do harm to other investors in the long-term.
\end{abstract}

high and tend to repurchase equity when market value is low. Moreover, Loughran and Ritter (1995, 1997), McLean, Pontiff, and Watanabe (2009) suggests a negative abnormal return after equity issuance, which is similar in a stock merger scenario (Loughran and Vijh (1997)), while Ikenberry, Lakonishok, and Vermaelen $(1995,2000)$ argue a positive long term stock performance after announcement of stock repurchase. Pontiff and Woodgate (2008) find out that share issuance is strongly negatively related to share issuance measures, using both Stephens and Weisbach (1998) and Daniel and Titman (2006) methods, so that SEO, stock merger and stock repurchase have return predict power and support the market timing hypothesis.

On the other hand, some scholars try to explain

*Corresponding Author:

Di Liu,

Central University of Finance and Economics, Chinese Academy of Finance and Development, No. 39 Xueyuan South Road, Haidian District, Beijing, 100081, China;

E-mail: 474846044@qq.com. 
cross-sectional stock return by investor sentiment theory. Unlike classical finance theory, investor sentiment regards investors' irrationality as a risk factor which may have significant impact on stock cross-sectional return. Baker and Wurgler (2006) find out that a broad range of market sentiment measures have significant effects on the cross-section of stock prices. Since there is no definitive or uncontroversial measure of sentiment, they construct a composite index of sentiment (Baker and Wurgler Sentiment Index) that is based on the common variation in six underlying proxies for sentiment: the closed-end fund discount, NYSE share turnover, the number and average first-day returns on IPOs, the equity share in new issues, and the dividend premium. McLean and Zhao (2014) use their approach and argue that investor sentiment affects external financing decision and its cost.

Inspired by them, in this paper, we are trying to investigate the logic beneath the share issuance activity, especially SEO, in China market. The market timing hypothesis of equity issuance is based upon three assumptions: Firstly, there exists information asymmetry between the firm and outside investors; Secondly, at least some outside investors are not aware of firm's willingness and ability to benefit from information advantage; Thirdly, outside investors who understand the information asymmetry are constrained in arbitrage. After the examination on China stock market from 2006 to 2019 using Pontiff and Woodgate (2008) approach and Fama-Macbeth (1973) regression, we notice that equity issuance, together with market return, momentum and controlling shareholders' participation, is positively and significantly related to cross-sectional performance of stock, especially in a long-term sense, which is inconsistent with what we find in the U.S. market. We also have a test on SEO pricing process through issuance discount and the result of it reveals that outside investors seem to be aware of the information asymmetry and want to be compensated by issuer.

The contradiction of assumptions on market timing hypothesis leads us to connect equity issuance and stock return performance from the sense of investor sentiment. It affects the market through investors' general attitude and behavioral pattern. Among the numerous investor sentiment measures, market turnover has a strong and positive predict power to future cross-sectional after SEO. Our test result indicates that the explanatory power of investor sentiment on the variation of return performance dominates that of share issuance, showing an irrefutable impact on equity issuance decision-making. A further test reveals that market turnover is also a good proxy for future share issuance, even better than funda-

\section{mental variables.}

Our paper contributes at least in three aspects. Firstly, our paper disputes the market timing hypothesis with data from China and challenges the reliability of investor's naivety to information asymmetry with issuance pricing process. Secondly, besides of the finding that the explanatory power of investor sentiment outweighs that of past share issuance, it is also a better indicator of future share issuance, leaving investor sentiment to a good risk factor. Thirdly, our empirical findings comply with the impact of investor sentiment on both corporate finance and asset pricing model through its predictability on equity issuance and return performance.

The rest of this paper is organized as follows. Section II describes the sample selection and variable construction of our study, followed by Section III with summary statistics. We test on the return predictability of share issuance in Section IV and influential factors of return performance in SEO event in In Section V. Section VI presents the dispute of market timing hypothesis with regression on issuance discount. Then we focus on investor sentiment and discuss the predict power on future return in Section VII and its indication on future equity issuance in Section VIII. Section IX is the conclusion.

\section{Data Description}

\subsection{Sample}

China stock market was established in late 1990, remarked by the foundation of Shanghai Stock Exchange (SHSE) and Shenzhen Stock Exchange (SZSE). Annual financial statement and monthly stock performance data is draw from CSMAR, a wildly used financial database, for all public firms, including those delisted or acquired by other firms, from 2006 to 2019 . We retain the firms with non-missing return entries and have been in the database for at least 6 months to computing the previous 6-month returns as momentum proxy. For each firm, we assign the annual financial statement data of last year after April to each firm-month observations, due to disclosure requirements by China Securities Regulatory Commission (CSRC). This leaves us 237,461 firm-month observations in total.

Fama and French (2005) state that equity financing activities include share repurchase, SEOs, stock mergers, and share issuance through executive compensation, conversion of convertible debt, and warrant exercise. Compared with those in developed countries, China stock market is quite young and experiences a wave of regulation changes in policy. In early age of China capital market, IPO was the main player in equity financing and SEO was 
not active. To mitigate the volatiles, SEO issue sample is draw from Wind and covers SEO data since 2006 when it was generally accepted as a main approach as equity financing. We have 4,035 SEO observations in the sample from 2006 to 2019 .

\subsection{ISSUE}

We use Pontiff and Woodgate (2008) method to construct share issuance variable ISSUE for each company. Firstly, we obtain the number of shares outstanding of each listed firm from CSMAR database and then adjust for stock splits and stock dividends. Thus, annual share issuance variable at time $t$ is computed as the logged difference of adjusted number of shares outstanding as

$$
\begin{gathered}
\text { ISSUE }_{\mathrm{t}, \mathrm{t}-11}=\operatorname{Ln}\left(\text { Adjusted Shares }_{\mathrm{t}}\right)-\operatorname{Ln}(\text { Adjusted } \\
\text { Shares } \left._{\mathrm{t}-11}\right)
\end{gathered}
$$

A positive figure of ISSUE $_{\mathrm{t}, \mathrm{t}-11}$ represent a stock issuance within that year while a negative figure appears when there is a stock repurchase.

In our regression model, we also try some other time intervals, such as 6-month and 3-year share issuance variables. We choose 1-year interval as audited financial statement data are required to release annually, which also corresponded to market capitalization and book-tomarket value measure introduced by Fama and French (1992). 6-month share issuance variables evaluate relatively short-term effect of share issuance and match the momentum proxy we construct as previous 6-month return. 3-year share issuance variables evaluate relative long-term effect of share issuance and match the minimum holding period of controlling shareholders who participate in SEO.

\section{$2.3 \mathrm{~B} / \mathrm{M}$}

We use the annual financial statement reported book value data to construct book-to-market variable B/M of each firm. Fama and French (1992) procedure compute the book value of firm at the end June of each year, but we do it at April of each year since financial statements are available at that time for all public firms. We assign financial statement data of previous financial year, including book value, to each month from April to March of next year. Book value then is divided by market value of the firm on December of previous year, giving us B/M.

\subsection{SIZE}

We calculate the monthly market value by multiplying assigned number of shares outstanding with month-end stock price. SIZE is the natural logarithm of monthly mar- ket value of the firm.

\subsection{MOM}

We use previous 6-month holding period return as momentum proxy (Jegadeesh and Titman (1993)). MOM is lagged by 1 month due to return synchronicity.

\subsection{Returns}

Month stock performance data as well as the market return data are draw from CSMAR. If return data is missing for certain month, we ignore it. The dependent variable in our model is the 6-month, 1-year and 3-year holding period return. 6-month holding period return represents the return one will receive from holding the stock for a relatively short investment horizon. We choose 1-year holding period return to measure a relatively long investment horizon, which also correspond to the minimum holding period for institutional investors who participate in SEO and have no connection to controlling shareholders. 3-year holding period return matches the minimum holding period of controlling shareholders who participate in SEO. We also have the equal-weighted market return with dividend reinvestment for all SHSE-listed firms, denoted as EWRET, as well as HS300 index return, donated as RETHS300.

\subsection{ISSUE_VOL, ISSUE_MV}

We obtain the SEO events data from Jan 2006 to Dec 2019 from Wind. Some events involve both seasonal offering and stock merger, and we do not distinguish them in our regression. ISSUE_VOL is the number of shares issued disclosed in SEO announcement and ISSUE_MV is the market value of shares issued in CNY.

\subsection{Discount}

With data from Wind and disclosure announcement, we compute the discount on issuance as to the close price of last trading day before issuance. Most of them are positive, suggesting a price discount for the investors. But in some scenarios, there exists issuance premium when the issuer is popular or the SEO market is active.

\subsection{Controlling Shareholders (CS), Controlling Shareholders Percent (CSP)}

Controlling Shareholder (CS) is a dummy variable set to one if the controlling shareholders participate in SEO, and zero otherwise. Controlling Shareholders Percent (CSP) is the portion of shares purchased by controlling shareholders. We construct the variable based on the public 
information from Wind and disclosure announcement and cannot rule out the cases that some controlling shareholders might take part in the SEO under cover trough some other investors.

\subsection{SOE}

It is a dummy variable set to one if the issuer is a stateowned enterprise, and zero otherwise. The classification is based on the ultimate shareholders of the firm. We do not specific them as central government owned firms or local government owned firms.

\subsection{ISSUE_PCT}

ISSUE_PCT is the proportion of equity issued as to firm's market value at the end of last month. Market value of issuance is obtained from Wind and disclosure announcement.

\subsection{Market Turnover (MKT_TR)}

Monthly market turnover (MKT_TR) is computed as total transaction value divided by the total market capitalization at the end of each month, averaging by number of trading days in that month. Data is draw from CSMAR.

\subsection{Capital Expenditure Ratio (CapEx)}

Capital expenditure ratio (CapEx) is computed as capital expenditure over net value of property, plant and equipment (PPE) measured at the end of last financial year. It reveals firm's extent on capital expansion and investment. Data is draw from CSMAR.

\subsection{Net Profit Margin (NPM)}

Net profit margin (NPM) is computed as net income over total revenue measured at the end of last financial year. It reveals firm's ability to generate profit. Data is draw from CSMAR.

\subsection{Return on Equity (ROE)}

Return on equity (ROE) is computed as net income over book value of equity measured at the end of last financial year. It reveals firm's profitability for shareholders. Data is draw from CSMAR.

\subsection{Earning Cash Ratio (ECR)}

Earning cash ratio (ECR) is computed as net operating cash flow over net income measured at the end of last financial year. It reveals firm's ability to generate free cash flow. Data is draw from CSMAR.

\section{Summary Statistics}

Table 1 presents the univariate statistics of variables in our paper. Panel A exhibits a strongly right-skewed market value of SEO sample, showing that our result might be dominated by those 'big issuers'. The average market value of issuance is 1.82 billion, slightly larger than $75^{\text {th }}$ percentile, 1.80 billion. In spite of $36 \%$ of controlling shareholders participate in SEO, they possess $49.28 \%$ of issued stocks. In some cases, the controlling shareholders take $90 \%$ of issued stocks, most in stock merger of controlling shareholders' other assets. In our SEO sample, $35 \%$ of the firms are state owned. Furthermore, 6-month holding period return before the SEO event is $29 \%$ on average, but some firms still experiences a negative momentum.

Panel B describes the correlation structure of our variables in SEO sample with their t-statistics. Large and/or value firms tend to issue more in the context of market value, which make sense as they probably finance more compared with small/growth firms in the amount of money. Momentum variable is also positively related to both issuance volume and issuance market value, which is consistent with market timing story. It appears that issuance discount is positively affected by market value of issuance, but the impact is subtle. It is also positively affected by the participation of controlling shareholders. When controlling shareholders is involved in SEO, they might have more bargaining power and influence on the pricing process. Growth firms tend to have lower discount. As most of their M\&A and investment is considered to have larger benefit compared with value firms, demand of their offering is higher as well, leading to a higher bidding price and lower discount.

Panel A presents the descriptive statistics for the variables of our main interest for stocks traded in SHSE and SZSE during January 2006 to Dec 2019, while panel B reports correlations among the variables. ISSUE_VOL is the number of shares issued in SEO. ISSUE_MV is market value of shares issued in SEO. DISCOUNT is the discount of issue price with respect to the closing price of last trading day before issuance. CS is the dummy variable set to one if the controlling shareholders participate in SEO, and zero otherwise. CSP is the percent of shares bought by controlling shareholders in SEO. SOE is the dummy variable set to one if issuer is stated owned, and zero otherwise. SIZE is the natural logarithm of market value of the firm. B/M is the book-to-market ratio from Fama and French (1992) computed as book value of equity from last financial year over market value of the firm on the end of last December. MOM is the momentum proxy 
Journal of Finance Research | Volume 04 | Issue 01 | April 2020

Table 1. Sample Summary Statistics

\begin{tabular}{|c|c|c|c|c|c|c|c|c|c|}
\hline \multicolumn{10}{|c|}{ Panel A Summary Statistics } \\
\hline Variable & Mean & P25 & Median & \multicolumn{3}{|c|}{ P75 } & \multicolumn{2}{|l|}{ SD } & $\mathrm{N}$ \\
\hline ISSUE_VOL & $220,533,252.71$ & $30,000,000.00$ & $70,000,000.00$ & \multicolumn{3}{|c|}{$181,653,042.00$} & \multicolumn{2}{|c|}{$675,311,821.29$} & 4,035 \\
\hline ISSUE_MV & $1,820,628,844.31$ & $419,999,969.31$ & $813,399,995.84$ & \multicolumn{3}{|c|}{$1,799,999,944.04$} & \multicolumn{2}{|c|}{$3,669,126,688.34$} & 4,035 \\
\hline DISCOUNT & 22.71 & 7.08 & 20.20 & \multicolumn{3}{|c|}{39.08} & \multicolumn{2}{|l|}{26.26} & 4,007 \\
\hline $\mathrm{CS}$ & 0.36 & 0.00 & 0.00 & \multicolumn{3}{|c|}{1.00} & \multicolumn{2}{|l|}{0.48} & 4,035 \\
\hline CSP & 49.28 & 16.43 & 40.00 & \multicolumn{3}{|c|}{97.14} & \multicolumn{2}{|l|}{36.79} & 1,491 \\
\hline SOE & 0.35 & 0.00 & 0.00 & \multicolumn{3}{|c|}{1.00} & \multicolumn{2}{|l|}{0.48} & 4,035 \\
\hline SIZE & 15.96 & 15.35 & 15.88 & \multicolumn{3}{|c|}{16.49} & \multicolumn{2}{|l|}{0.91} & 4,035 \\
\hline $\mathrm{B} / \mathrm{M}$ & 0.21 & 0.10 & 0.17 & \multicolumn{3}{|c|}{0.27} & 0.17 & & 4,035 \\
\hline MOM & 0.29 & -0.06 & 0.13 & \multicolumn{3}{|c|}{0.44} & 0.70 & & 3,926 \\
\hline \multicolumn{10}{|c|}{ Panel B Correlations } \\
\hline Variable & ISSUE_VOL & ISSUE_MV & DISCOUNT & $\mathrm{CS}$ & CSP & SOE & SIZE & $\mathrm{B} / \mathrm{M}$ & MOM \\
\hline ISSUE_VOL & 1 & & & & & & & & \\
\hline ISSUE_MV & 0.77 & 1 & & & & & & & \\
\hline DISCOUNT & 0.06 & 0.03 & 1 & & & & & & \\
\hline $\mathrm{CS}$ & 0.07 & 0.07 & 0.02 & 1 & & & & & \\
\hline CSP & 0.05 & 0.04 & 0.10 & 0.26 & 1 & & & & \\
\hline SOE & 0.12 & 0.12 & -0.08 & 0.18 & 0.03 & 1 & & & \\
\hline SIZE & 0.39 & 0.61 & 0.04 & 0.04 & 0.01 & 0.06 & 1 & & \\
\hline $\mathrm{B} / \mathrm{M}$ & 0.22 & 0.17 & -0.36 & 0.16 & 0.01 & 0.27 & 0.11 & 1 & \\
\hline MOM & 0.07 & 0.04 & 0.39 & -0.01 & 0.08 & -0.06 & 0.10 & -0.23 & 1 \\
\hline
\end{tabular}

from Jegadeesh and Titman (1993), computed as the cumulative return from previous 6 months, and lagged by 1 month.

\section{Return Predictability of Share Issuance}

In this section, we use Pontiff and Woodgate (2008) method to explore the return predictability of equity issuance for China market from 2006 to 2019. In the sense of Fama and MacBeth (1973), we run separate regressions using ISSUE variables with different time intervals and several holding-period returns for each month of data. We also consider book-to-market ratio $(\mathrm{B} / \mathrm{M})$, market capitalization (SIZE) and momentum (MOM) as control variables. Our model is stated as followed,

\section{RETURN $=\alpha+\beta_{1} *$ ISSUE $+\beta_{2} * \mathrm{~B} / \mathrm{M}+\beta_{3} * \mathrm{SIZE}+\beta_{4} *$ $\mathrm{MOM}+\varepsilon$}

Four-time intervals to compute ISSUE variable (3-month, 6-month, 1-year and 3-year) and six holding period returns (3-month, 6-month, 9-month, 1-year, 2-year and 3-year) are considered.

The estimation result is presented in Table 2. Panel A states the test of different holding period returns on 3-month ISSUE. The sign of the slope coefficients for three control variables are consistent with previous studies: the slope coefficient on $\mathrm{B} / \mathrm{M}$ is positive and significant, the slope coefficient on SIZE is negative and significant, and the slope coefficient on MOM is positive and significant. The slope coefficient on ISSUE $_{t,-3-3}$ is statistically significant for four future returns. For the first 3-month and 6-month, ISSUE $\mathrm{t}_{\mathrm{t},-3}$ has a negative impact on return performance, implying the market timing story. However, for a relatively long run performance, ISSUE $\mathrm{t}_{\mathrm{t}, \mathrm{t}-\mathrm{3}}$ contributes to future stock return. The positive return predictability is stronger when we using ISSUE variable with longer past time interval. ISSUE $\mathrm{t}_{\mathrm{t}, \mathrm{-}-6}$ is still negatively and significantly impact 3-month stock return, but it turns to positive on 6-month stock return and afterward. As we can see in annual issuance variable IS$\mathrm{SUE}_{\mathrm{t}, \mathrm{t}-12}$, cross-sectional returns for all six holding period have positive and significant slope coefficient.

Table 2 presents the result of Fama-MacBeth regression of cross-sectional returns on share issuance from January 2006 to Dec 2019 in China capital market. The dependent variable is cumulative return of stocks in 3-month, 6-month, 9-month, 1-year, 2-year and 3-year. The independent variables include share issuance variable ISSUE (Pontiff and Woodgate (2006)) on previous 3-month, 6-month, 1-year and 3-year. SIZE is the natural logarithm of market value of the firm. B/M is the book-to-market ratio from Fama and French (1992) computed as book value of equity from last financial year over market value of the firm on the end of last December. MOM is the momentum proxy from Jegadeesh and Titman (1993), computed as the cumulative return from previous 6 months, and lagged by 1 month. Adjusted $\mathrm{R}^{2}$ statistics reflect within variations. Robust t-statistics with Newey-West (1987) corrections are reported in the parentheses. *Significant at $10 \%$; ** significant at $5 \%$; ***significant at $1 \%$.

Overall, we interpret the result of Fama-MacBeth re- 
Journal of Finance Research | Volume 04 | Issue 01 | April 2020

Table 2. Share Issuance and Cross-sectional Return

\begin{tabular}{|c|c|c|c|c|c|c|}
\hline \multicolumn{4}{|c|}{ Panel A Regression on ISSUE of last 3 months } & \multirow[b]{2}{*}{ RET_12M } & \multirow[b]{2}{*}{ RET_24M } & \multirow[b]{2}{*}{ RET_36M } \\
\hline & RET_3M & RET_6M & RET_9M & & & \\
\hline \multirow[t]{2}{*}{ Intercept } & $1.484 * * *$ & $2.191 * * *$ & $2.979 * * *$ & $3.009 * * *$ & $3.195 * * *$ & $-0.236 * * *$ \\
\hline & {$[147.06]$} & {$[131.88]$} & {$[130.51]$} & {$[103.17]$} & [84.79] & {$[-4.28]$} \\
\hline \multirow[t]{2}{*}{ ISSUE_P3 } & $-0.038 * * *$ & $-0.033 * * *$ & $0.079 * * *$ & $0.081 * * *$ & $0.145^{* * *}$ & $0.107 * * *$ \\
\hline & {$[-6.72]$} & {$[-3.51]$} & [6.12] & [4.89] & [6.81] & {$[3.44]$} \\
\hline \multirow[t]{2}{*}{ B/M } & $0.033 * * *$ & $0.091 * * *$ & $0.150 * * *$ & $0.226^{* * *}$ & $0.310 * * *$ & $0.212 * * *$ \\
\hline & {$[20.86]$} & {$[35.63]$} & {$[42.54]$} & {$[50.23]$} & {$[53.18]$} & [24.91] \\
\hline \multirow[t]{2}{*}{ SIZE } & $-0.029 * * *$ & $-0.073^{* * *}$ & $-0.121 * * *$ & $-0.185^{* * *}$ & $-0.263 * * *$ & $-0.124 * * *$ \\
\hline & {$[-43.23]$} & [-65.95] & [-79.69] & {$[-95.35]$} & {$[-104.85]$} & {$[-33.87]$} \\
\hline \multirow[t]{2}{*}{ MOM } & $0.063 * * *$ & $0.116^{* * *}$ & $0.105 * * *$ & $0.061 * * *$ & $-0.075 * * *$ & $0.083 * * *$ \\
\hline & {$[43.83]$} & {$[49.37]$} & {$[32.31]$} & {$[14.80]$} & {$[-14.03]$} & {$[10.56]$} \\
\hline \multirow[t]{3}{*}{ Adj R-square } & $0.017 * * *$ & $0.033 * * *$ & $0.039 * * *$ & $0.053 * * *$ & $0.068 * * *$ & $0.008 * * *$ \\
\hline & 3 Regression 0 & of last 6 mon & & & & \\
\hline & RET_3M & RET_6M & RET_9M & RET_12M & RET_24M & RET_36M \\
\hline \multirow[t]{2}{*}{ Intercept } & $1.483 * * *$ & $2.198 * * *$ & $2.986^{* * *}$ & $3.013 * * *$ & $3.207 * * *$ & $-0.221 * * *$ \\
\hline & {$[146.81]$} & [132.14] & {$[130.65]$} & {$[103.16]$} & [85.01] & {$[-4.01]$} \\
\hline \multirow[t]{2}{*}{ ISSUE_P6 } & $-0.022 * * *$ & $0.030 * * *$ & $0.081 * * *$ & $0.061 * * *$ & $0.143 * * *$ & $0.145^{* * *}$ \\
\hline & {$[-5.42]$} & {$[4.46]$} & {$[8.69]$} & {$[5.14]$} & {$[9.27]$} & {$[6.43]$} \\
\hline \multirow[t]{2}{*}{$\mathbf{B} / \mathbf{M}$} & $0.032 * * *$ & $0.093 * * *$ & $0.151 * * *$ & $0.227 * * *$ & $0.311 * * *$ & $0.214 * * *$ \\
\hline & {$[20.79]$} & {$[36.00]$} & [42.77] & {$[50.28]$} & [53.42] & {$[25.14]$} \\
\hline \multirow[t]{2}{*}{ SIZE } & $-0.029 * * *$ & $-0.073 * * *$ & $-0.122 * * *$ & $-0.185 * * *$ & $-0.264 * * *$ & $-0.125 * * *$ \\
\hline & {$[-43.05]$} & {$[-66.40]$} & {$[-79.92]$} & {$[-95.29]$} & {$[-105.06]$} & {$[-34.17]$} \\
\hline \multirow[t]{2}{*}{ MOM } & $0.063 * * *$ & $0.115^{* * *}$ & $0.104 * * *$ & $0.061 * * *$ & $-0.076 * * *$ & $0.080 * * *$ \\
\hline & {$[43.72]$} & {$[48.57]$} & [32.05] & {$[14.79]$} & {$[-14.28]$} & {$[10.26]$} \\
\hline \multirow[t]{3}{*}{ Adj R-square } & $0.017 * * *$ & $0.033 * * *$ & $0.039 * * *$ & $0.053 * * *$ & $0.069 * * *$ & $0.009 * * *$ \\
\hline & Regression o & of last $12 \mathrm{mor}$ & & & & \\
\hline & RET_3M & RET_6M & RET_9M & RET_12M & RET_24M & RET_36M \\
\hline \multirow[t]{2}{*}{ Intercept } & $1.493 * * *$ & $2.209 * * *$ & $3.005 * * *$ & $3.056 * * *$ & $3.259 * * *$ & $-0.196 * * *$ \\
\hline & [144.45] & [129.82] & {$[128.38]$} & {$[102.07]$} & {$[84.57]$} & {$[-3.49]$} \\
\hline \multirow[t]{2}{*}{ ISSUE_P12 } & $0.013 * * *$ & $0.033 * * *$ & $0.065^{* * *}$ & $0.100^{* * *}$ & $0.193^{* * *}$ & $0.220 * * *$ \\
\hline & [4.09] & {$[6.44]$} & [9.21] & {$[11.06]$} & [16.69] & [12.99] \\
\hline \multirow[t]{2}{*}{$\mathbf{B} / \mathbf{M}$} & $0.033 * * *$ & $0.092 * * *$ & $0.150 * * *$ & $0.228 * * *$ & $0.313 * * *$ & $0.215^{* * *}$ \\
\hline & {$[20.86]$} & [35.49] & [41.95] & {$[49.64]$} & [53.09] & {$[25.00]$} \\
\hline \multirow[t]{2}{*}{ SIZE } & $-0.030 * * *$ & $-0.074 * * *$ & $-0.123 * * *$ & $-0.188 * * *$ & $-0.268 * * *$ & $-0.128 * * *$ \\
\hline & {$[-43.01]$} & [-65.35] & {$[-78.56]$} & {$[-94.21]$} & {$[-104.14]$} & {$[-34.06]$} \\
\hline MOM & $0.060 * * *$ & $0.114 * * *$ & $0.105^{* * *}$ & $0.061 * * *$ & $-0.076 * * *$ & $0.078 * * *$ \\
\hline & {$[41.65]$} & {$[47.64]$} & [31.92] & {$[14.50]$} & {$[-14.15]$} & {$[9.96]$} \\
\hline Adj R-square & $0.017 * * *$ & $0.032 * * *$ & $0.039 * * *$ & $0.053 * * *$ & $0.069 * * *$ & $0.009 * * *$ \\
\hline & Regression 0 & of last $36 \mathrm{mor}$ & & & & \\
\hline & RET_3M & RET_6M & RET_9M & RET_12M & RET_24M & RET_36M \\
\hline Intercept & $1.495 * * *$ & $2.249 * * *$ & $3.064 * * *$ & $3.157 * * *$ & $3.323 * * *$ & $-0.375 * * *$ \\
\hline & [122.37] & [111.35] & [111.12] & [89.43] & {$[74.60]$} & {$[-5.64]$} \\
\hline ISSUE_P36 & $0.019 * * *$ & $0.045^{* * *}$ & $0.067 * * *$ & $0.091 * * *$ & $0.150 * * *$ & $0.296 * * *$ \\
\hline & {$[8.79]$} & {$[12.36]$} & [13.63] & {$[14.44]$} & {$[18.90]$} & [24.99] \\
\hline B/M & $0.032 * * *$ & $0.089 * * *$ & $0.146^{* * *}$ & $0.222 * * *$ & $0.302 * * *$ & $0.222 * * *$ \\
\hline & {$[18.12]$} & {$[30.89]$} & [37.13] & [43.95] & {$[47.43]$} & [23.33] \\
\hline SIZE & $-0.030^{* * *}$ & $-0.077^{* * *}$ & $-0.127 * * *$ & $-0.196^{* * *}$ & $-0.274 * * *$ & $-0.124 * * *$ \\
\hline & {$[-36.44]$} & {$[-56.74]$} & {$[-68.46]$} & {$[-82.27]$} & {$[-91.35]$} & {$[-27.67]$} \\
\hline MOM & $0.060 * * *$ & $0.108 * * *$ & $0.095^{* * *}$ & $0.046^{* * *}$ & $-0.096 * * *$ & $0.048 * * *$ \\
\hline & {$[36.97]$} & {$[40.46]$} & {$[26.08]$} & {$[9.94]$} & {$[-16.35]$} & {$[5.48]$} \\
\hline Adj R-square & $0.016^{* * *}$ & $0.030 * * *$ & $0.037 * * *$ & $0.052 * * *$ & $0.069 * * *$ & $0.009 * * *$ \\
\hline
\end{tabular}

gression as that share issuance variables, especially longterm ones, have a strong and positive return predictability in the long run, which is inconsistent with the U.S. market. It appears that a recent share issuance might depress stock return for several months, but after the fade away of supply pressure, stock price of the firm will converge with better estimation and higher valuation. On the second thought, the average $\mathrm{R}^{2}$ s suggest that issuance variables may not have such strong explanatory power on cross-sectional variance, but we can still draw the conclusion that equity issuance may have positive impact on future stock returns, which is a contradiction to market timing hypothesis. 
Journal of Finance Research | Volume 04 | Issue 01 | April 2020

Table 3. Factors Impact Future Returns After SEO

\begin{tabular}{|c|c|c|c|c|c|c|c|c|}
\hline & RET_6M & RET_6M & RET_12M & RET_12M & RET_24M & RET_24M & RET_36M & RET_36M \\
\hline \multirow[t]{2}{*}{ Intercept } & $0.917 * * *$ & $0.893 * * *$ & $2.001 * * *$ & $1.967 * * *$ & $2.114 * * *$ & $2.047 * * *$ & $0.862^{* *}$ & $0.855^{* *}$ \\
\hline & {$[4.67]$} & [4.55] & {$[8.24]$} & {$[8.08]$} & {$[8.30]$} & {$[8.02]$} & {$[2.46]$} & {$[2.43]$} \\
\hline \multirow[t]{2}{*}{ CS } & & $0.050 * *$ & & $0.053 *$ & & $0.055^{*}$ & & $0.047^{*}$ \\
\hline & & {$[2.06]$} & & {$[1.70]$} & & {$[1.68]$} & & {$[1.69]$} \\
\hline \multirow[t]{2}{*}{ SOE } & & $-0.046^{*}$ & & $-0.061^{*}$ & & $-0.103^{* * * *}$ & & -0.022 \\
\hline & & {$[-1.91]$} & & {$[-1.95]$} & & {$[-3.15]$} & & {$[-0.49]$} \\
\hline \multirow[t]{2}{*}{ CMKT_RET_6M } & $0.970 * * *$ & $0.969^{* * *}$ & & & & & & \\
\hline & [30.68] & {$[30.53]$} & & & & & & \\
\hline \multirow[t]{2}{*}{ CMKT_RET_12M } & & & $0.796^{* * *}$ & $0.794 * * *$ & & & & \\
\hline & & & {$[32.12]$} & {$[31.85]$} & & & & \\
\hline \multirow[t]{2}{*}{\begin{tabular}{|l} 
CMKT_RET_24M \\
\end{tabular}} & & & & & $0.738 * * *$ & $0.732 * * *$ & & \\
\hline & & & & & [32.19] & [31.79] & & \\
\hline \multirow[t]{2}{*}{ CMKT_RET_36M } & & & & & & & $0.738^{* * * *}$ & $0.739^{* * *}$ \\
\hline & & & & & & & [31.34] & [31.13] \\
\hline \multirow[t]{2}{*}{$\mathbf{B} / \mathbf{M}$} & $-0.139 * *$ & $-0.144 * *$ & -0.065 & -0.064 & -0.116 & -0.094 & $-0.259 * *$ & $-0.273 * *$ \\
\hline & {$[-2.30]$} & {$[-2.30]$} & {$[-0.84]$} & {$[-0.79]$} & {$[-1.41]$} & {$[-1.10]$} & {$[-2.28]$} & {$[-2.33]$} \\
\hline \multirow[t]{2}{*}{ SIZE } & $-0.055^{* * * *}$ & $-0.053^{* * * *}$ & $-0.129 * * *$ & $-0.127^{* * * *}$ & $-0.156^{* * * *}$ & $-0.150^{* * * *}$ & $-0.090 * * *$ & $-0.090^{* * * *}$ \\
\hline & {$[-4.57]$} & {$[-4.39]$} & {$[-8.39]$} & {$[-8.16]$} & {$[-9.52]$} & {$[-9.16]$} & {$[-3.99]$} & {$[-3.95]$} \\
\hline \multirow[t]{2}{*}{ мом } & $-0.051^{* *}$ & $-0.053^{* *}$ & -0.011 & -0.014 & $-0.055^{*}$ & $-0.060^{* *}$ & -0.029 & -0.03 \\
\hline & {$[-2.35]$} & {$[-2.44]$} & {$[-0.40]$} & {$[-0.50]$} & {$[-1.89]$} & {$[-2.06]$} & {$[-0.73]$} & {$[-0.75]$} \\
\hline Adj R-square & $0.451 * * *$ & $0.453 * * *$ & $0.496^{* * *}$ & $0.498^{* * * *}$ & $0.518^{* * *}$ & $0.522 * * *$ & $0.463^{* * * *}$ & $0.463^{* * * *}$ \\
\hline
\end{tabular}

\section{Factors Influence Future Return on Equity Issuance}

We further investigate the short-term and long-term co-movement between future stock returns and equity issuance factors within the SEO sample. From Jan 2006 to Dec 2019, we run several Fama-MacBeth regressions on different holding period cross-sectional returns for those firms which have completed equity issuance. We consider some factors that might have impact the return performance, including controlling shareholders' participation dummy (CS) and state-owned dummy (SOE). The control variables are corresponding market returns (MKT_RETURN), book-to-market ratio (B/M), market capitalization (SIZE) and momentum (MOM). Our model is stated as followed,

\section{RETURN $=\alpha+\beta_{1} * \mathrm{CS}+\beta_{2} * \mathrm{SOE}+\beta_{3} *$ MKT_RE- TURN $+\beta_{4} * \mathrm{~B} / \mathrm{M}+\beta_{5} * \mathrm{SIZE}+\beta_{6} * \mathrm{MOM}+\varepsilon$}

We consider four holding period returns (6-month, 1-year, 2-year and 3-year) and the estimation result is presented in Table 3. For each set of holding period, we run two tests. First one has only control variables as independent variables, and the second one includes SEO factors.
The sign of the slope coefficients for control variables are generally consistent with previous studies. Market returns are positively and significantly correlated to future stock performance in our SEO sample as we expected, since most firms have a positive beta. Smaller firms, measured as capital size, tend to have a better return performance. It makes sense that small firms are generally more sensitive to financial improvement and/or investor sentiment than larger firms (Baker and Wurgler (2002)). Growth firms experience higher stock returns than value firms, but the outcome is not consistent in most cases. The slope coefficients on CS dummy are positive and significant for four holding period returns. Involvement of controlling shareholders in equity issuance combines the interests of controlling shareholders and outside investors, relaxing their concern of information asymmetry. Also, it gives firm' managers more incentives to improve profitability and stock performance, benefitting the controlling shareholders. The slope coefficients on SOE dummy are negative and significant for 6-month, 1-year and 2-year holding period returns. Most SOEs in China sometimes have to carry out more social responsibilities or maintain social stability (see Bai, Lu and Tao (2006), Ho(2008), Dewenter and Malatesta (2000), Li and Zhang (2010), and Kolk, Hong 
and van Dolen (2010)), resulting to a lower profitability and efficiency than those privately owned firms. We also take cumulative capital expenditure into consideration, but the test result is not significant for all four holding period returns.

Table 3. presents the result of Fama-MacBeth regression of cross-sectional returns on several factors after SEO from January 2006 to Dec 2019 in China capital market. The dependent variable is cumulative return of stocks in 6-month, 1-year, 2-year and 3-year. CS is the dummy variable set to one if the controlling shareholders participate in SEO, and zero otherwise. SOE is the dummy variable set to one if issuer is stated owned, and zero otherwise. CMKT_RET is the cumulative market return with different time intervals including 6-month, 1-year, 2 -year and 3-year. SIZE is the natural logarithm of market value of the firm. $\mathrm{B} / \mathrm{M}$ is the book-to-market ratio from Fama and French (1992) computed as book value of equity from last financial year over market value of the firm on the end of last December. MOM is the momentum proxy from Jegadeesh and Titman (1993), computed as the cumulative return from previous 6 months, and lagged by 1 month. Adjusted $\mathrm{R}^{2}$ statistics reflect within variations. Robust t-statistics with Newey-West (1987) corrections are reported in the parentheses. *Significant at $10 \% ; * *$ significant at $5 \% ; * * *$ significant at $1 \%$.

For all models in this section, we observe a positive and significant abnormal return, which is consistent with what we find in last section. The stock performance of those SEO firms outweighs the market in cross-sectional consistently, despite of the participation of controlling shareholders or entity property. If firms take advantage of information asymmetry and issue equity when its valuation is high, its stock price should revert to intrinsic value afterward, at least in the long run. Our findings in China market dispute the market timing hypothesis in some extent. The three assumptions laid on it are these: first, controlling shareholders have information advantage on outside investors; second, at least some outside investors are not aware of controlling shareholders' willingness and ability to time the market; third, although some outside investors understand the information asymmetry, they are constrained in arbitrage. In next section, we will investigate the pricing process of SEO to figure out the reliability of these assumptions.

\section{Issuance Discount and Controlling Share- holders}

Share issuance discount is a mirror reflecting information asymmetry and market timing of controlling shareholder. Larrain and Urzua (2013) argue that share issuance in general predict low future returns due to information asymmetry and outside investors' naivety. The underperformance is more pronounced in the absence of institutional investors and in a hot issuance market. Chan and Chan (2014) show that a better information environment, such as higher analyst coverage, can mitigate the negative relation between SEO discount and stock return synchronicity.

We take Fama-MacBeth regressions on SEO discount in our sample with model below:

$$
\begin{gathered}
\text { DISCOUNT }=\alpha+\beta_{1} * \text { ISSUE_PCT }+\beta_{2} * \mathrm{CS}+\beta_{3} * \mathrm{SOE} \\
+\beta_{4} * \text { CapEx }+\beta_{5} * \mathrm{~B} / \mathrm{M}+\beta_{6} * \mathrm{SIZE}+\beta_{7} * \mathrm{MOM}+\varepsilon
\end{gathered}
$$

Test results are shown in Table 4. Growth firms tend to have higher discount on equity issuance, partly because after the approval of equity issuance by CSRC, their stock price rise more sharply due to higher sensitivity than value firms. It coincides with a positive and significant relation between issuance discount and momentum. Large firms have higher discount as their issuance volume are usually large. The slope coefficient on issuance percentage is positive and significant as expected. Controlling shareholders usually have bargain power on listed firm with which outside investors are willing to share, resulting to a higher issuance discount. In addition, SOE dummy contributes to issuance discount negatively, but the impact is insignificant.

Table 4 presents the result of Fama-MacBeth regression of issuance discount in SEO on several factors from January 2006 to Dec 2019 in China capital market. The dependent variable is issuance discount with respect to closing price of last trading day before issuance. ISSUE PCT is the proportion of equity issued as to firm's market value at the end of last month. CS is the dummy variable set to one if the controlling shareholders participate in SEO, and zero otherwise. SOE is the dummy variable set to one if issuer is stated owned, and zero otherwise. CapEx is the capital expenditure ratio computed as capital expenditure over net value of property, plant and equipment (PPE) measured at the end of last financial year. SIZE is the natural logarithm of market value of the firm. B/M is the book-to-market ratio from Fama and French (1992) computed as book value of equity from last financial year over market value of the firm on the end of last December. MOM is the momentum proxy from Jegadeesh and Titman (1993), computed as the cumulative return from previous 6 months, and lagged by 1 month. Adjusted $\mathrm{R}^{2}$ statistics reflect within variations. Robust t-statistics with Newey-West (1987) corrections are reported in the 
parentheses. ${ }^{*}$ Significant at $10 \% ; * *$ significant at $5 \%$; $* * *$ significant at $1 \%$.

Table 4. Factors Impact Issuance Discount in SEO

\begin{tabular}{|c|c|c|c|c|c|}
\hline & $\mathbf{( 1 )}$ & $\mathbf{( 2 )}$ & $\mathbf{( 3 )}$ & $\mathbf{( 4 )}$ & $\mathbf{( 5 )}$ \\
\hline Intercept & 10.951 & 7.448 & 7.089 & 6.756 & 6.615 \\
\hline & {$[1.53]$} & {$[1.03]$} & {$[0.98]$} & {$[0.93]$} & {$[0.91]$} \\
\hline $\begin{array}{c}\text { ISSUE } \\
\text { PCT }\end{array}$ & & $0.004 * * *$ & $0.003 * * *$ & $0.004 * * *$ & $0.003 * * *$ \\
\hline & & {$[2.90]$} & {$[2.74]$} & {$[2.82]$} & {$[2.80]$} \\
\hline CS & & & $3.359 * * *$ & $3.459 * * *$ & $3.451 * * *$ \\
\hline & & & {$[3.91]$} & {$[3.99]$} & {$[3.98]$} \\
\hline SOE & & & & -0.743 & -0.757 \\
\hline & & & & {$[-0.80]$} & {$[-0.81]$} \\
\hline CapEx & & & & & -0.406 \\
\hline & & & & & {$[-1.44]$} \\
\hline B/M & $-42.208 * * *$ & $-42.948 * * *$ & $-44.429 * * *$ & $-43.967 * * *$ & $-44.097 * * *$ \\
\hline & {$[-17.52]$} & {$[-17.75]$} & {$[-18.19]$} & {$[-17.51]$} & {$[-17.55]$} \\
\hline SIZE & $1.060^{* *}$ & $1.253 * * *$ & $1.228 * * *$ & $1.253 * * *$ & $1.274 * * *$ \\
\hline & {$[2.37]$} & {$[2.78]$} & {$[2.73]$} & {$[2.78]$} & {$[2.82]$} \\
\hline MOM & $12.100^{* * *}$ & $12.081 * * *$ & $12.036 * * *$ & $12.020^{* * * *}$ & $11.998 * * *$ \\
\hline & {$[20.50]$} & {$[20.49]$} & {$[20.45]$} & {$[20.42]$} & {$[20.37]$} \\
\hline $\begin{array}{c}\text { Adj } \\
\text { R-square }\end{array}$ & $0.237 * * *$ & $0.239 * * *$ & $0.243 * * *$ & $0.243 * * *$ & $0.243 * * *$ \\
\hline
\end{tabular}

Considering the significance of slope coefficient on several factors, including issuance percent, controlling shareholder's participation and momentum, it is sound that outside investors are aware of the information asymmetry and want to be compensated by issuance discount. We also report average profitability and capital expenditure of SEO firms 3 years before and after issuance in Table 5. It appears that neither profitability nor capital expenditure of the firms' average has improved after equity issuance. In all, market timing theory may not hold in China stock market and we try to disentangle the mystery with investor sentiment theory in next section.

Table 5 presents the profitability, capital expenditure and valuation 3 years before and after SEO from January 2006 to Dec 2019 in China capital market. CapEx is the capital expenditure ratio computed as capital expenditure over net value of property, plant and equipment (PPE) measured at the end of last financial year. NPM is the net profit margin computed as net income over total revenue measured at the end of last financial year. ROE is the return on equity computed as net income over book value of equity measured at the end of last financial year. ECR is the earning cash ratio computed as net operating cash flow over net income measured at the end of last financial year. B/M is the bookto-market ratio from Fama and French (1992) computed as book value of equity from last financial year over market value of the firm on the end of last December.

Table 5. Profitability, Capital Expenditure and Valuation around SEO

\begin{tabular}{|c|c|c|c|c|c|c|c|}
\hline $\begin{array}{c}\text { Vari- } \\
\text { able }\end{array}$ & $\begin{array}{c}\text { 3-year } \\
\text { before }\end{array}$ & $\begin{array}{c}\text { 2-year } \\
\text { before }\end{array}$ & $\begin{array}{c}\text { 1-year } \\
\text { before }\end{array}$ & $\begin{array}{c}\text { SEO } \\
\text { year }\end{array}$ & $\begin{array}{c}\text { 1-year } \\
\text { after }\end{array}$ & $\begin{array}{c}\text { 2-year } \\
\text { after }\end{array}$ & $\begin{array}{c}\text { 3-year } \\
\text { after }\end{array}$ \\
\hline CapEx & 1.199 & 0.334 & 0.405 & 1.169 & 0.367 & 0.295 & 0.253 \\
\hline NPM & 0.563 & 0.634 & 0.907 & 0.109 & 0.102 & 0.082 & 0.052 \\
\hline ROE & 0.029 & 0.350 & 0.178 & 0.082 & 0.074 & 0.062 & 0.104 \\
\hline ECR & 1.161 & 0.223 & 0.388 & 0.074 & 0.053 & 0.091 & 0.058 \\
\hline B/M & 0.384 & 0.365 & 0.283 & 0.335 & 0.360 & 0.390 & 0.434 \\
\hline
\end{tabular}

\section{Investor Sentiment and Cross-Sectional Return of SEO}

Investor sentiment measures the general attitude of investors towards a security or market at a given time, including future payoffs, investment risks, etc. Two basic assumptions of how investor sentiment affects stock return are: first, investors are subject to sentiment; second, rational investors are limited to arbitrage (See De Long et al. (1990), Shleifer and Vishny (1997), etc.). Studies on stock market performance, especially in crashes (Kindleberger (2001) and Shiller (2000)), show a nice pattern of how investor sentiment cooperates with the return performance.

Prior research suggests that there are a number of approximation methods for investor sentiment (mutual fund flow, trading volume, close-end fund discount, option implied volatility, first day return of IPO, equity issues over total issue and so on), in spite of the fact that none of them is definitive or uncontroversial. Among them, market turnover is generally accepted as an investor sentiment measure. We construct monthly China A-share market turnover MKT_TR as trading market value of SHSE and SZSE A-share over total market capitalization of two exchanges, averaging by number of trading days in each month. Intuitively, the more optimistic of investor, the higher MKT_TR is. From Jan 2006 to Dec 2019, market turnover is volatile, representing a deteriorate investor sentiment.

Similarly, we implement Fama-MacBeth approach to discover the relation between investor sentiment and cross-sectional return. We run separate regressions on several holding period returns for each month with annual issuance variable ISSUE $\mathrm{t}_{\mathrm{t}, \mathrm{t}-11}$ and monthly market turnover MKT_TR. Regression model is stated as,

$$
\begin{gathered}
\text { RETURN= } \alpha+\beta_{1} * \text { ISSUE }+\beta_{2} * \text { MKT_TR }+\beta_{3} * \mathrm{~B} / \mathrm{M} \\
+\beta_{4} * \mathrm{SIZE}+\beta_{5} * \mathrm{MOM}+\varepsilon
\end{gathered}
$$

Four-time intervals to compute ISSUE variable (3-month, 6-month, 1-year and 3-year) and six hold- 
Table 6. Investor Sentiment and Cross-sectional Return

\begin{tabular}{|c|c|c|c|c|c|c|c|c|c|c|c|c|}
\hline \multirow[t]{2}{*}{ Panel A } & \multicolumn{6}{|c|}{ Regression on cross-sectional returns with ISSUE of last 3 months } & \multirow[b]{2}{*}{ RET_12M } & \multirow[b]{2}{*}{ RET_12M } & \multirow[b]{2}{*}{ RET_24M } & \multirow[b]{2}{*}{ RET_24M } & \multirow[b]{2}{*}{ RET_36M } & \multirow[b]{2}{*}{ RET_36M } \\
\hline & RET_3M & RET_3M & RET_6M & RET_6M & RET_9M & RET_9M & & & & & & \\
\hline \multirow{2}{*}{ Intercept } & $1.540 * * *$ & $539 * * *$ & $2.261 * * *$ & $262 * * *$ & $3.060 * * *$ & $3.070 * * *$ & $3.098 * * *$ & $3.108 * * *$ & $3.274 * * *$ & $3.288 * * *$ & -0.068 & -0.053 \\
\hline & {$[157.43]$} & 57.24] & 138.68] & |38.60] & $36.20]$ & 36.54] & 107.40] & [107.67] & [87.37] & [87.70] & {$[-1.25]$} & {$[-0.97]$} \\
\hline \multirow[t]{2}{*}{ MKT_TR } & $0.024 * * *$ & $23 * * *$ & $0.030 * * *$ & $030 * * *$ & $0.038 * * *$ & $0.039 * * *$ & $0.042 * * *$ & $0.042 * * *$ & $0.039 * * *$ & $0.040 * * *$ & $0.077 * * *$ & $0.078 * * *$ \\
\hline & {$[114.21]$} & 14.00] & 37.94] & 87.87] & {$[81.06]$} & $1.48]$ & [68.47] & [68.81] & [49.65] & [50.06] & [67.37] & {$[67$} \\
\hline \multirow[t]{2}{*}{ ISSUE_P3 } & & & & 007 & & & & & & & & \\
\hline & & .32] & & & & & & & & [9.30] & & \\
\hline \multirow[t]{2}{*}{$\mathbf{B} / \mathbf{M}$} & $35 * * *$ & $0.035 * * *$ & ** & $0.094 * * *$ & $52 * * *$ & $0.153 * * *$ & $228 * * *$ & 0.230 & $0.311 * * *$ & $0.313 * * *$ & $0.216^{* * *}$ & $0.219^{* *}$ \\
\hline & & {$[22.82]$} & [37.31] & [37.31] & [43.78] & [44.17] & [51.30] & [51.60] & [53.73] & {$[54.08]$} & {$[25.71]$} & [25.97] \\
\hline \multirow[t]{2}{*}{ SIZE } & $-0.043 * * *$ & $-0.043 * * *$ & $-0.091 * * *$ & $-0.091 * * *$ & $-0.143 * * *$ & $-0.144 * * *$ & $-0.209 * * *$ & $-0.210 * * *$ & $-0.285 * * *$ & $-0.287 * * *$ & $-0.170 * * *$ & $-0.171 * * *$ \\
\hline & & 7] & {$[-82.81]$} & {$[-82.68]$} & & & {$[-107.46]$} & {$[-10$} & {$[-11$} & {$[-113.09]$} & & \\
\hline MOM & 0 & * & & * & & & -0.03 & -0.0 & -0.16 & -0.16 & -0.09 & \\
\hline & & & & & & & & & & & & \\
\hline Adj R-square & $0.077 * * *$ & $0.077 * * *$ & 0.06 & 0.06 & $0.070 * * *$ & & $0.075 * * *$ & $0.075 * * *$ & & $0.080 * * *$ & $0.030 * * *$ & $0.031 * * *$ \\
\hline Panel B & Regressi & on cr & tiona & ns with ISSU & $\mathrm{E}$ of last $6 \mathrm{~m}$ & ionths & & & & & & \\
\hline & RET_ & RET $3 \mathrm{~N}$ & RET_6M & RET_6M & & RET_9M & RET & RET & RET & $\mathrm{M}$ & $\mathrm{RI}$ & RET \\
\hline & & & & & & & 2.27 & 3.0 & 3.0 & $3.0 \mathrm{~s}$ & 3.1 & \\
\hline & & & & & & & & & & & & \\
\hline MKT_TR & & 0.04 & 0.07 & 207 & & & 0.0 & 0.0 & & 0.04 & 0.0 & \\
\hline & {$[11$} & {$[5$} & & & & & [88.26] & & & [68 & & \\
\hline ISSI & & 0.18 & & & & & $0.060 * * *$ & & & & & \\
\hline & & & & & & & & & & & & \\
\hline B/M & & 0 . & & k* & & & 0.0 & & & & & \\
\hline & & & & & & & & & & & & \\
\hline SIZE & -0.0 & -0. & -0.1 & $* *$ & & & -0.0 & -0.1 & -0.1 & -0.2 & -0.2 & \\
\hline & & ] & & {$[-4$} & & & & & & {$[-10$} & & \\
\hline MOM & & & -0.0 & -0.1 & & & & 0.0 & & -0.0 & & \\
\hline & & & & & & & & & & & & \\
\hline uare & $0.077 * * *$ & 0.0 & 0.03 & 0.03 & 0.0 & & & & & & & \\
\hline & & & & & & & & & & & & \\
\hline & & & RE & $\mathrm{RE}$ & & $9 \mathrm{M}$ & RET_12M & RET_12M & & RET_24M & & \\
\hline Int & & & & & & & $2.283 * * *$ & $3.076 * * *$ & $3.100 * * *$ & $3.124 * * *$ & $3.160 * * *$ & 3.28 \\
\hline & & & & & & & & & & & & \\
\hline MK' & & $* *$ & 0.07 & $* *$ & & & 0.03 & 0.0 & & 0.0 & 0.0 & 0.040 \\
\hline & & & & & & & & & & & & \\
\hline & & & & & & & 0.0 & & & & & \\
\hline & & & & & & & & & & & & \\
\hline $\mathbf{B} / \mathbf{M}$ & $* * *$ & 0.3 & & $* *$ & $* * *$ & & 0.09 & $* * *$ & 0.15 & $226 * * *$ & *** & $0.307 * * *$ \\
\hline & & & & & & & & & & & & \\
\hline SIZE & & & -0.1 & $* *$ & & & $-0.0 \mathrm{~S}$ & -0.1 & -0.1 & $-0.211 * * *$ & -0.2 & $-0.286^{* * *}$ \\
\hline & & & & & & & & & & & & \\
\hline MOM & & & -0.0 & & & & 0.0 & 0.0 & & -0.0 & -0.0 & -0.1 \\
\hline & & & & & & & & & & {$[-7$} & {$[-8$} & ] \\
\hline j R-square & $0.078^{* * *}$ & $0.081 * * *$ & $0.031 * * *$ & $0.032 * * *$ & $0.078 * * *$ & $0.069 * * *$ & $0.069^{* * *}$ & $0.070^{* * *}$ & $0.070 * * *$ & $0.075 * * *$ & $0.076^{* * *}$ & $0.079^{* * *}$ \\
\hline Panel D & Regress & 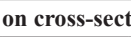 & tional & s w & Eo & no & & & & & & \\
\hline & & PET 3N & & RET_6M & $9 \mathrm{M}$ & RET_9M & RET_1 & RET_ & RET_2 & RET_24M & RET_. & RET \\
\hline & & & & & & & & & & & & \\
\hline & & & & & & & & & & & & \\
\hline MKT_TR & & 0.04 & 0.08 & 0.08 & & & 0.03 & 0.04 & 0.0 & $0.044^{* * *}$ & $0.044 * * *$ & $0.041 * * *$ \\
\hline & {$[105.27]$} & & [66.63] & [66.92] & & {$[81.50]$} & [81.62] & [73.79] & [73.92] & {$[61.51]$} & {$[61.64]$} & {$[45.08]$} \\
\hline ISSUE_TJO & & $0.152 * * *$ & & $0.301 * * *$ & $0.020 * * *$ & & $0.046^{* * *}$ & & $0.069 * * *$ & & $0.093 * * *$ & \\
\hline & &  & & & & & {$[13$} & & {$[1$} & & {$[14$} & \\
\hline & & & & & & & & & & 0.2 & & 0.2 \\
\hline & & & & & & & & & & & & \\
\hline SIZE & $-0.046 * * *$ & $-0.303 * * *$ & $-0.154 * * *$ & $-0.187^{* * *}$ & $-0.048 * * *$ & $-0.095 * * *$ & $-0.100 * * *$ & $-0.148 * * *$ & $-0.156 * * *$ & $-0.216 * * *$ & $-0.227 * * *$ & $-0.286^{* * *}$ \\
\hline & {$[-58.36]$} & {$[-99.33]$} & {$[-35.41]$} & {$[-41.32]$} & {$[-58.75]$} & {$[-72.84]$} & {$[-73.61]$} & {$[-82.75]$} & {$[-83.47]$} & {$[-93.77]$} & {$[-94.24]$} & {$[-97.76]$} \\
\hline MOM & & $-0.188 * * *$ & $-0.154 * * *$ & $-0.153 * * *$ & & $0.034 * * *$ & $0.034 * * *$ & & & $-0.053 * * *$ & $-0.052 * * *$ & $-0.189 * * *$ \\
\hline & & & & & & & & & {$[0.80]$} & {$[-10.82]$} & {$[-10.73]$} & {$[-30.4$} \\
\hline $\mathbf{e}$ & $0.081 * * *$ & $0.081^{* * *}$ & $0.033 * * *$ & $0.037 * * *$ & $0.082 * * *$ & $0.069 * * *$ & $0.070^{* * *}$ & $0.069 * * *$ & $0.070 * * *$ & $0.073 * * *$ & $0.075 * * *$ & $0.079 * * *$ \\
\hline
\end{tabular}


ing period returns (3-month, 6-month, 9-month,1-year, 2 -year and 3-year) are considered in the model and result is presented in Table 6 . The slope coefficients of market turnover are positive and significant for all ISSUE time intervals and holding period returns, indicating that investor sentiment measure also has a strong predictability to cross-sectional return. Until now, it appears that investor sentiment has an even better explanatory power on cross-sectional return than ISSUE with better consistency across different time interval and higher t-statistics. To move on, we explore the relation between future equity issuance and investor sentiment in next section.

Table 6 presents the result of Fama-MacBeth regression of cross-sectional returns on share issuance from January 2006 to Dec 2019 in China capital market. The dependent variable is cumulative return of stocks in 3-month, 6-month, 9-month, 1-year, 2-year and 3-year. The independent variables include share issuance variable ISSUE (Pontiff and Woodgate (2006)) on previous 3-month, 6-month, 1-year and 3-year. MKT_TR is the monthly market turnover computed as total transaction value divided by the total market capitalization at the end of each month, averaging by number of trading days in that month. SIZE is the natural logarithm of market value of the firm. B/M is the book-to-market ratio from Fama and French (1992) computed as book value of equity from last financial year over market value of the firm on the end of last December. MOM is the momentum proxy from Jegadeesh and Titman (1993), computed as the cumulative return from previous 6 months, and lagged by 1 month. Adjusted R2 statistics reflect within variations. Robust t-statistics with Newey-West (1987) corrections are reported in the parentheses. *Significant at $10 \%$; ** significant at $5 \% ; * * *$ significant at $1 \%$.

\section{Investor Sentiment and Equity Issuance}

Our test on investor sentiment and equity financing decision-making is implemented by the model below,

ISSUE $=\alpha+\beta_{1} *$ MKT_TR $+\beta_{2} *$ CapEx $+\beta_{3} * \mathrm{NPM}+\beta_{4}$ $* \mathrm{ROE}+\beta_{5} * \mathrm{ECR}+\beta_{6} * \mathrm{~B} / \mathrm{M}+\beta_{7} * \mathrm{SIZE}+\beta_{8} * \mathrm{MOM}+\varepsilon$

Four-time intervals to compute ISSUE variable are considered, including 6-month, 1-year, 2-year and 3-year ahead. Test result in Table 7 states that as an investor sentiment measure, market turnover is a good indicator to future issuance variable in both short-term and long-term, with positive and significant coefficient. Its performance is more consistent than those of fundamentals, such as capital expenditure, net profitability and ROE.

Table 7 presents the result of Fama-MacBeth regression of share issuance ISSUE on investor sentiment measure market turnover from January 2006 to Dec 2019 in China capital market. The independent variables include share issuance variable ISSUE (Pontiff and Woodgate (2006)) on next 6-month, 1-year, 2-year and 3-year. MKT_TR is the monthly market turnover computed as total transaction value divided by the total market capitalization at the end of each month, averaging by number of trading days in that month. CapEx is the capital expenditure ratio computed as capital expenditure over net value of property, plant and equipment (PPE) measured at the end of last financial year. NPM is the net profit margin computed as net income over total revenue measured at the end of last financial year. ROE is the return on equity computed as net income over book value of equity measured at the end of last financial year. ECR is the earning cash ratio computed as net operating cash flow over net income measured at the end of last financial year. SIZE is the natural logarithm of market value of the firm. B/M is the book-to-market ratio from Fama and French (1992) computed as book value of equity from last financial year over market value of the firm on the end of last December. MOM is the momentum proxy from Jegadeesh and Titman (1993), computed as the cumulative return from previous 6 months, and lagged by 1 month. Adjusted $\mathrm{R}^{2}$ statistics reflect within variations. Robust t-statistics with Newey-West (1987) corrections are reported in the parentheses. *Significant at $10 \%$; $* *$ significant at $5 \%$; ***significant at $1 \%$.

Table 7. Investor Sentiment and Share Issuance

\begin{tabular}{|c|c|c|c|c|}
\hline & ISSUE_6M & ISSUE_12M & ISSUE_24M & ISSUE_36M \\
\hline Intercept & $-0.046^{* * *}$ & -0.004 & $0.253^{* * *}$ & $0.606 * * *$ \\
\hline & {$[-8.47]$} & {$[-0.46]$} & {$[20.98]$} & {$[39.26]$} \\
\hline MKT_TR & $0.003 * * *$ & $0.005 * * *$ & $0.011^{* * *}$ & $0.012 * * *$ \\
\hline & {$[26.18]$} & {$[32.23]$} & {$[43.49]$} & {$[37.94]$} \\
\hline CapEx & 0.000 & 0.000 & $0.000^{* * *}$ & $0.001 * * *$ \\
\hline & {$[0.36]$} & {$[0.15]$} & {$[3.40]$} & {$[9.01]$} \\
\hline NPM & 0.000 & 0.000 & 0.000 & 0.000 \\
\hline & {$[0.54]$} & {$[0.74]$} & {$[0.27]$} & {$[0.54]$} \\
\hline ECR & $-0.000^{* *}$ & $-0.000^{* * *}$ & $-0.000 * * *$ & $-0.000^{* * *}$ \\
\hline & {$[-2.07]$} & {$[-3.82]$} & {$[-4.84]$} & {$[-5.21]$} \\
\hline ROE & 0.000 & 0.000 & -0.000 & $-0.000^{* *}$ \\
\hline & {$[0.54]$} & {$[0.63]$} & {$[-1.13]$} & {$[-2.20]$} \\
\hline B/M & $-0.023 * * *$ & $-0.038^{* * *}$ & $-0.049 * * *$ & $-0.055^{* * *}$ \\
\hline & {$[-27.19]$} & {$[-30.99]$} & {$[-26.41]$} & {$[-23.16]$} \\
\hline SIZE & $0.006 * * *$ & $0.006 * * *$ & $-0.004 * * *$ & $-0.020^{* * *}$ \\
\hline & {$[16.25]$} & {$[12.18]$} & {$[-5.52]$} & {$[-19.24]$} \\
\hline MOM & $0.021 * * *$ & $0.040^{* * *}$ & $0.048^{* * *}$ & $0.044 * * *$ \\
\hline & {$[24.49]$} & {$[33.61]$} & {$[25.82]$} & {$[18.58]$} \\
\hline Adj R-square & $0.018^{* * *}$ & $0.026 * * *$ & $0.024 * * *$ & $0.017 * * *$ \\
\hline & & & & \\
\hline
\end{tabular}


To summarize, market turnover gives a strong and positive predication to cross-sectional return performance in China capital market. Compared with that of share issuance, its impact is more consistent in both long run and short run. Market turnover is also a good proxy for future share issuance, even better than fundamental variables measure financial status of the firm. It seems that explanatory power share issuance have on variation of cross-sectional return is dominated by that of investor sentiment.

\section{Conclusion}

The mispricing story between equity financing and return performance is in a long-existing debate among scholars. Some may explain the predictability of share issuance on cross-sectional return as firm's willingness and ability to time the market with information advantage. With assumptions of market timing hypothesis that outside investors are naïve to acknowledge the information asymmetry or restricted to arbitrage, firm is able to issue equity when its valuation is high, resulting to a negative abnormal return after SEO.

However, our empirical findings on China capital market from 2006 to 2019 suggest the other way. In addition to positive relation between share issuance and future stock return, we find that outside investors are aware of information asymmetry and willing to be compensated by issuance discount, contradicting to the assumption of outside investor's naivety in market timing hypothesis. Our test result also reveals that as an investor sentiment measure, market turnover has a strong and positive predict power to future stock performance after SEO. Besides that, its explanatory power on the variation of cross-sectional return dominates that of share issuance, market turnover is also a good proxy of share issuance, even better than fundamental variables.

Our paper indicates that investor sentiment can shed light on decision-making process of equity issuance as well as cross-sectional return performance after SEO in China capital market. Its implications may help us better understand the market and behavioral finance pattern of investors, as well as provide a better risk factor in asset pricing model.

\section{References}

[1] Baker, Malcolm, and Jeffrey Wurgler, 2002, Market timing and capital structure, Journal of Finance 57, $1-32$.

[2] Baker, Malcolm, and Jeffrey Wurgler, 2006, Investor sentiment and the cross-section of stock returns,
Journal of Finance 61, 1645-1680.

[3] Baker, Malcolm, and Jeffrey Wurgler, 2007, Investor sentiment in the stock market, Journal of Economic Perspectives 21, 129-157.

[4] Bai, Chong-en, Jiangyong Lu and Zhigang Tao, 2006, The Multitask Theory of State Enterprise Reform: Empirical Evidence from China, American Economic Review 96(2), 353-357.

[5] Chan, Kalok, and Y.C. Chan, 2014, Price informativeness and stock return synchronicity: Evidence from the pricing of seasoned equity offerings, Journal of Financial Economics 114, 36-53.

[6] Daniel, Kent, and Sheridan Titman, 2006, Market reaction to tangible and intangible information, Journal of Finance 61, 1605-1643.

[7] De Long, J. Bradford, Andrei Shleifer, Lawrence H. Summers, and Robert J. Waldmann, 1990, Noise trader risk in financial markets, Journal of Political Economy 98:4, 703-738.

[8] Dewenter, K., and P. Malatesta, 2000, State-Owned and Privately-Owned Firms: An Empirical Analysis of Profitability, Leverage, and Labor Intensity, American Economic Review 320-334.

[9] Fama, Eugene F., and Kenneth R. French, 1992, The cross-section of expected stock returns, Journal of Finance 47, 427-465.

[10] Fama, Eugene F., and Kenneth R. French, 2005, Financing decisions: Who issues stock?, Journal of Financial Economics 76, 549-582.

[11] Fama, Eugene F., and James D. Macbeth, 1973, Risk, return, and equilibrium: Empirical tests, Journal of Political Economy 71, 607-636.

[12] Graham, John, and Campbell Harvey, 2001, The theory and practice of corporate finance: Evidence from the field, Journal of Financial Economics 60, 187243.

[13] Ho, B., 2008, CSR as "No. 1" issue for state-owned enterprises in China, CSR Asia Weekly 4(2):1-2.

[14] Ikenberry, David, Josef Lakonishok, and Theo Vermaelen, 1995, Market underreaction to open market share repurchases, Journal of Financial Economics 39, 181-208.

[15] Ikenberry, David, Josef Lakonishok, and Theo Vermaelen, 2000, Stock repurchases in Canada: Performance and strategic trading, Journal of Finance 55, 181-208.

[16] Jegadeesh, Narasimhan, and Sheridan Titman, 1993, Returns to buying winners and selling losers: Implications for stock market efficiency, Journal of Finance 48, 65-91.

[17] Kindleberger, Charles, 2001, Manias, Panics, and Crashes (Wiley, New York). 
[18] Kolk, A., P. Hong, and W. van Dolen, 2010, Corporate social responsibility in China: an analysis of domestic and foreign retailers' sustainability dimensions, Business Strategy and the Environment 19(5), 289-303.

[19] Larrain, Borja, and Francisco Urzua I., 2013, Controlling shareholders and market timing in share issuance, Journal of Financial Economics 109, 661-681.

[20] Li, W. and R. Zhang, 2010, Corporate social responsibility, ownership structure, and political interference: Evidence from China, Journal of Business Ethics 96:631-645.

[21] Loughran, Tim, and Jay Ritter, 1995, The new issues puzzle, Journal of Finance 50, 23-51.

[22] Loughran, Tim, and Jay Ritter, 1997, The operating performance of firms conducting new issues, Journal of Finance 52, 1823-1850.

[23] Loughran, Tim, and Anand Vijh, 1997, Do long-term shareholders benefit from corporate acquisitions? Journal of Finance 52, 1765-1790.
[24] McLean, R. David, Jeffrey Pontiff, and Akiko Watanabe, 2009, Share issuance and cross-sectional returns: International evidence, Journal of Financial Economics 94, 1-17.

[25] McLean, R. David and Mengxin Zhao, 2014, The business cycle, investor sentiment, and costly external finance, Journal of Finance 69 (3), 1377-1409.

[26] Newey, Whitney K, and Kenneth D West, 1987, Hypothesis testing with efficient method of moments estimation, International Economic Review 777-787.

[27] Pontiff, Jeffrey, and Artemiza Woodgate, 2008, Share issuance and cross-sectional returns, Journal of Finance 63, 921-945.

[28] Shiller, Robert J., 2000, Irrational Exuberance, Princeton University Press.

[29] Shleifer, Andrei, and Robert Vishny, 1997, The limits of arbitrage, Journal of Finance 52, 35-55.

[30] Stephens, Clifford P., and Michael S. Weisbach, 1998, Actual share acquisitions in open-market repurchase programs, Journal of Finance 52, 313-333. 